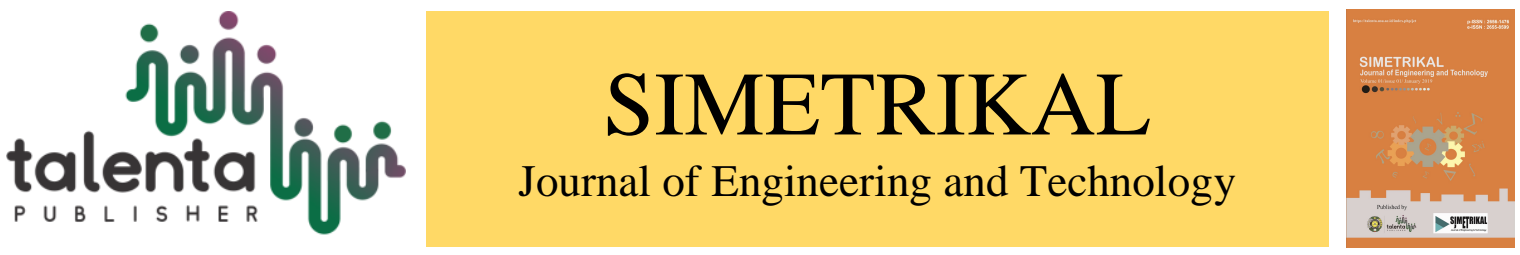

\title{
The Analysis of Water Availability and Power Plant Performance Relation Using Water Balance Method: Case of PT. INALUM Asahan
}

\author{
Syamsul Amien ${ }^{1}$, Yohanna Zellin ${ }^{1}$, and Fahmi Fahmi ${ }^{1,2}$ \\ ${ }^{I}$ Department of Electrical Engineering, Faculty of Engineering, University Sumatera Utara, Medan \\ ${ }^{2}$ Sustainable Energy and Biomaterials Centre of Excellent, University Sumatera Utara, Medan
}

\begin{abstract}
Hydroelectric power plant is a generator that uses water as a prime mover to rotate the water turbine in generating electrical energy which will then be used for industrial activities. A problem in the process of generating electrical energy is how to maximize the available water resources for optimal power generation. This study will discuss the relationship of water availability with power generation performance at PLTA PT Inalum by using water balance method. Water balance method is a method used to find out how much water discharge that will be issued to a dam so that output water later can be utilized to optimally generate power. This study found that the obtained power was generated at peak load of 560.19 MW and therefore the discharge of water issued at the dam is equal to 134.05 tons / sec. This study obtained a different trend pattern every year, where in 2015 trend pattern rose, in the year 2016 there was a relatively constant trend and in the year 2017 the pattern downward.
\end{abstract}

Keyword: Hydroelectric, power plant, power generation, water debit

\begin{abstract}
Abstrak. Pembangkit Listrik Tenaga Air (PLTA) merupakan suatu pembangkit yang menggunakan air sebagai penggerak mula untuk memutar turbin air dalam membangkitkan energi listrik yang kemudian akan dipakai untuk kebutuhan industri. Permasalahan pada proses pembangkitan energi listrik tersebut yaitu bagaimana memaksimalkan sumber daya air yang tersedia untuk pembangkitan daya yang optimal. Pada penelitian ini, akan dibahas bagaimana hubungan ketersediaan air dengan pembangkitan daya pada PLTA PT Inalum dengan menggunakan metode Water Balance. Metode Water Balance adalah metode yang digunakan untuk mengetahui berapa besar debit air yang akan dikeluarkan bendungan sehingga air yang keluar nantinya dapat dimanfaatkan sebaik mungkin untuk membangkitkan daya yang optimal. Dari hasil penelitian, diperoleh daya yang dibangkitkan pada saat beban puncak sebesar 560.19 MW sehingga debit air yang dikeluarkan pada bendungan yaitu sebesar 134.05 ton/sec. Didapatkan pola trend yang berbeda setiap tahunnya, dimana pada tahun 2015 terjadi pola trend naik, pada tahun 2016 terjadi pola trend yang relatif konstan dan pada tahun 2017 terjadi pola trend yang menurun.
\end{abstract}

Kata Kunci: pembangkit listrik tenaga air, pembangkitan daya, debit air

Received 6 November 2018 | Revised 25 January 2019| Accepted 31 January 2019

\footnotetext{
*Corresponding author at: Department of Electrical Engineering, University of Sumatera Utara, Jl. Almamater Kampus USU Medan, 20155, Sumatera Utara, Indonesia

E-mail address: fahmimn@usu.ac.id
} 


\section{Introduction}

Currently, the need for a source of electrical energy is very demanding for industry, as well as for PT Inalum which requires a large electrical energy to be able to produce aluminum which has continuously growing demands for aluminum over time. In the process of this aluminum formation, PT Inalum gets electricity supply from hydro power plant (PLTA) Siguragura and Tangga.

Inalum builds and operates PLTA Siguragura hydro power plant from power station located in Paritohan, Toba Samosir regency, North Sumatra. The Siguragura power station is operated by utilizing the Asahan river water that flows from Lake Toba. The total power generated depends on the condition of Lake Toba water availability. Electric power generated by Siguragura hydro power plant is used to melt aluminum at Inalum Kuala Tanjung smelter.

PLTA Siguragura has 4 generators which each generator produces power of $79.4 \mathrm{kVA}$, as well as PLTA Tangga has 4 generators which each generator produces power of $88 \mathrm{kVA}$. The power is then channeled to smelting plants in Kuala Tanjung and also for the daily use of Inalum employees in Paritohan and Kuala Tanjung, for example: street lights, home lights, office and etc.

Intake Dam for PLTA Tangga is built of Inalum from concrete and bow-shaped (concrete arch) which is the first arc dam in Indonesia and has considerable dimensions. Landing dam as the ladder serves as a water container that will be used to generate electricity at the power station. It was built in May 1978 and completed in August 1982. The height of the dam is 82 meters from the bottom of the Asahan River, with a volume of 4.880 .000 meter cubic.

Siruar regulating dam serves as a controll of Lake Toba water level and flowing water into the Asahan river, to be used to generate electricity in the Siguragura and PLTA Tangga. It was built in June 1978 and completed in January 1981. The Siruar regulator dam is a Concrete Gravity structure with a dam high 39 meters from the Asahan river basin.

One of the problems of power plant process in PLTA is how to maximize the available water resources to get optimal power generation [1]. The main factor affecting electric energy which will be generated by PLTA is the availability of water covering water debit [2]. Therefore, in this study examined the relationship of water availability in PLTA Siguragura and PLTA Tangga with the hydroelectric power plant performance with power generation PT Inalum as a case study. 


\section{Material and Methods}

\subsection{General}

Hydroelectric power plant (hydropower) is a generator that relies on potential and kinetic energy from water to generate electrical energy. The potential energy is the energy that an object possesses because of its position to the ground, and the kinetic energy is the energy that an object possesses because of its motion. The main form of this type of power plant is a generator that is connected to a turbine driven by water kinetic power.

The working principle of the hydroelectric power plant are based on water contained in a dam, then water is flown in through the intake gate [3]. It continously enter into the pipe rapidly (penstock). Water then flows into the turbine, and then there is a change of potential energy into kinetic energy. Water that enters the turbine will flow through the guide fins (fixed blades) which will then push the runner on the turbine. Falling water will drive the propeller causing the turbine to spin. Furthermore, in the turbine there is a change of kinetic energy into mechanical energy. The generator is connected to the turbine through the rotating teeth so that when the turbine blades rotate then the generator spins. The generator further converts the mechanical energy from the turbine into electrical energy.

\subsection{Turbine and Generator}

A turbine is a rotating machine that takes energy from a fluid stream. The moving fluid makes the rotating blades generate energy to drive the rotor. Turbine serves to convert potential energy into mechanical energy [4]. The falling force that drives the propeller causes the turbine to spin. Water turbines are mostly like windmills, by replacing the wind-thrust function to rotate propellers to be replaced by water to rotate turbine blades. The turbine is connected or coupled to the generator [5]-[7].

A generator is a device that can convert mechanical energy into electrical energy. Generator is closely related to Faraday's law, ie when a conductor is rotated inside a magnetic field so as to bypass the lines of magent force then at the end of the carrier will arise emf (electric force force) having unit in volt [7]-[9].

\subsection{Hydroelectric Dam}

\subsubsection{Regulatory Dam}

Dams are constructions built to hold water lanes into temporary storage pools. The dam has a section called a water gate to dispose of unwanted water gradually or sustainably. Regulatory dam serves to regulate the water level of Lake Toba and the stability of water out of Lake Toba to Asahan river to supply water to the power station constantly [9]-[11]. 


\subsubsection{Siguragura Dam}

The Siguragura Water Supply Dam (Siguragura Intake Dam) is located in Simorea and serves as a stable water source for Siguragura power station. The water contained in the dam is used in the siguragura power station located $200 \mathrm{~m}$ inside the earth with 4 generator units and the total capacity of the four generators is $280 \mathrm{MW}$ [11], [12].

\subsubsection{Ladder Dam}

Ladder Dam is located on the Staircase and serves to contain water that has been used PLTA Siguragura to be reused at PLTA Tangga $[11,12]$.

\subsection{Power and Water Debit}

Electrical power is the amount of effort in moving the charge per unit time or shorter is the amount of electrical energy used every second. Water debit is a measure of the amount of volume of water that can pass in a place or that can be accommodated in a place every single time unit [9].

\subsection{Water Balance Method}

Water Balance is the amount of water entering the dam equal to the large water coming out of the dam. In this study at Siguragura hydropower plant, the water balance calculation itself is the proper opening of Regulation Dam (RGD) to meet the Siguragura Power Station (SGP) and Tangga Power Station (TNP) power generation without any advantages or lack of water in Siguragura Dam (SGD) neither in Tangga Dam (TND). This method is aimed at making the water level of SGD and TND can be maintained at constant level, since there is no surplus or lack of water in each Dam and the demand for electric power should be continously fulfilled.

Several steps of calculation and the formula used in the Water Balance Method will be explain in detail below.

First, calculated the value of Ps:

$$
\text { Ps }=\frac{1}{2} x \text { Ptot }
$$

Then we calculated the value of the water debit for each turbine in PLTA Siguragura and PLTA Tangga :

$$
\begin{aligned}
& Q s 1=\left(-0.0000001702 x P s 1^{4}+0.00003748 x P s 1^{3}-0.002305 x P s 1^{2}+0.491 x P s 1+2.854,2\right) \\
& Q s 2=\left(-0.0000002993 x P t 2^{4}+0.00007051 x P t 2^{3}-0.004921 x P t 2^{2}+0.547 x P t 2+2.497,2\right) \\
& Q s 3=\left(-0.0000003837 x P s 3^{4}+0.0000981 x P s 3^{3}-0.006909 x P s 3^{2}+0.599 x P s 3+2.331,2\right) \\
& Q s 4=\left(-0.0000002947 x P s 4^{4}+0.00006872 x P s 4^{3}-0.004585 x P s 4^{2}+0.553 x P s 4+2.973,2\right) \\
& Q t 1=\left(0.0000005486 x P t 1^{4}-0.00007379 x P t 1^{3}+0.002982 x P t 1^{2}+0.425 x P t 1+3.3,2\right) \\
& Q t 2=\left(-0.0000002993 x P t 2^{4}+0.00007051 x P t 2^{3}-0.004921 x P t 2^{2}+0.547 x P t 2+2.497,2\right)
\end{aligned}
$$




$$
\begin{aligned}
& Q t 3=\left(0.0000002926 x P t 3^{4}-0.00003221 x P t 3^{3}+0.0007242 x P t 3^{2}+0.453 x P t 3+2.644,2\right) \\
& Q t 4=\left(0.0000007593 x P t 4^{4}-0.0001176 x P t 4^{3}+0.005776 x P t 4^{2}+0.347 x P t 4+2.598,2\right)
\end{aligned}
$$

After the value obtained from the water debit, then we calculated the value of $\Delta \mathrm{Q}$ :

$$
\Delta Q=Q s+L F t-Q t
$$

When the value of $\Delta \mathrm{Q} \neq 0$, then calculated values $\Delta \mathrm{P}, \mathrm{Ps}, \mathrm{Pt}$ and, ie :

$$
\begin{aligned}
& \Delta P=\left(\frac{71.5}{79.2}\right) x \Delta Q \\
& P t=P t o t-P s
\end{aligned}
$$

Then go back to the formula 1, and then continued to do the calculations for the formula 2 to formula 9. Recalculate the value of $\Delta \mathrm{Q}$ as in formula 10 .

When $\Delta \mathrm{Q}=0$, then it concluded the water was in balance. Do the calculation to find the Qrgd value.

$$
\text { Qrgd }=Q s-L F S
$$

After the value obtained Qrgd, then the calculation has been completed.

With,

Ptot $=$ The total power that PT Inalum will generate $(M W)$,

$P s=$ Power in Siguragura $(M W)$,

$P t=$ Power on the Stairs $(M W)$,

$Q s 1, Q s 2, Q s 3 . Q s 4=$ Water debit in Siguragura $($ ton $/ \mathrm{sec})$,

$Q t 1, Q t 2, Q t 3, Q t 4=$ Water debit on the Stairs (ton/sec),

Qrgd = Water debit at Regulating Dam will be issued for use in power generation of PLTA Siguragura and PLTA Tangga (ton/sec),

$L F t=$ Local Inflow on the Stairs $($ ton/sec)

LFs = Local Inflow in Sigura (ton/sec).

\subsection{Research methods}

The research was conducted at the hydroelectric power plant PT. INALUM located in Paritohan, Kec. Pantiupohan Meranti Toba Samosir, North Sumatra. The flowchart of research can be seen in Figure 1. 


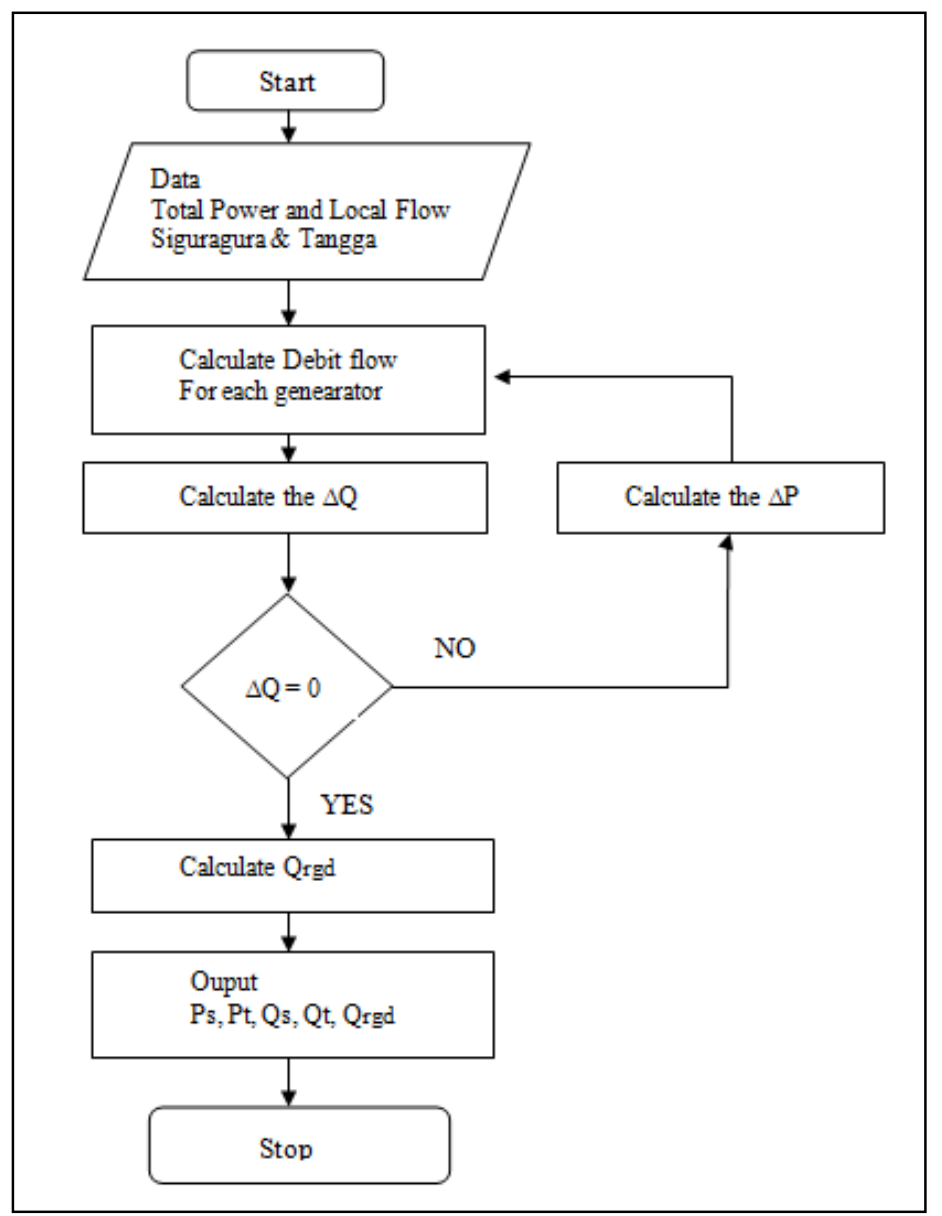

Figure 1. Flowchart of Water Balance Method

\section{Results}

Table 1 shows the results of calculations performed in analyzing the relationship of water availability and power generation PLTA PT Inalum during 2015-2017.

Table 1. Result of Calculation using Water Balance Method

\begin{tabular}{ccccccc}
\hline \multirow{2}{*}{ Year } & Month & \multicolumn{3}{c}{ POWER (P) } & \multicolumn{3}{c}{ DEBIT (Q) } \\
\cline { 3 - 7 } & & $\begin{array}{c}\text { Ps } \\
\text { (MW) }\end{array}$ & $\begin{array}{c}\text { Pt } \\
\text { (MW) }\end{array}$ & $\begin{array}{c}\text { Qs } \\
\text { (ton/sec) }\end{array}$ & $\begin{array}{c}\text { Qt } \\
\text { (ton/sec) }\end{array}$ & $\begin{array}{c}\text { Orgd } \\
\text { (ton/sec) }\end{array}$ \\
\hline \multirow{6}{*}{2015} & Jan & 281.8 & 134.5 & 137.1 & 128.8 & 269.4 \\
& Feb & 279.8 & 135.5 & 136.1 & 131.7 & 271.2 \\
& Mar & 285.3 & 137.8 & 138.8 & 135.0 & 275.9 \\
& Apr & 270.2 & 282.9 & 134.9 & 137.6 & 128.3 \\
& May & 265.5 & 281.4 & 132.6 & 136.9 & 125.9 \\
& Jun & 250.1 & 260.3 & 124.9 & 126.8 & 119.1 \\
& Jul & 257.9 & 265.3 & 128.7 & 129.2 & 123.9 \\
& Aug & 264.5 & 274.8 & 132.1 & 133.7 & 126.4 \\
& Sep & 265.5 & 277.3 & 132.6 & 134.9 & 126.5 \\
& Oct & 263.1 & 282.0 & 131.4 & 137.2 & 124.6 \\
& Nov & 267.3 & 285.5 & 133.5 & 138.9 & 125.1 \\
& Dec & 266.8 & 289.9 & 133.2 & 141.1 & 123.2 \\
\hline \multirow{3}{*}{2016} & Jan & 221.0 & 247.3 & 111.0 & 120.5 & 101.2 \\
& Feb & 228.6 & 239.3 & 114.5 & 117.5 & 108.5 \\
& Mar & 264.5 & 275.8 & 132.1 & 134.2 & 127.9 \\
& Apr & 261.6 & 278.9 & 130.6 & 135.7 & 124.3 \\
\hline
\end{tabular}


Table 1. Result of Calculation using Water Balance Method

\begin{tabular}{ccccccc}
\hline \multirow{3}{*}{ Year } & Month & \multicolumn{3}{c}{ POWER (P) } & DEBIT (Q) & \\
\cline { 3 - 7 } & & Ps & $\begin{array}{c}\text { Pt } \\
(\text { MW })\end{array}$ & $\begin{array}{c}\text { Qs } \\
\text { (MW) }\end{array}$ & $\begin{array}{c}\text { Qt } \\
\text { (ton/sec) }\end{array}$ & $\begin{array}{c}\text { Qrgd } \\
\text { (ton/sec) }\end{array}$ \\
\hline \multirow{4}{*yyyyy}{} & May & 259.2 & 277.1 & 129.4 & 134.8 & 117.6 \\
& Jun & 266.5 & 278.4 & 133.1 & 135.4 & 124.4 \\
& Jul & 268.0 & 277.2 & 133.8 & 134.8 & 128.2 \\
& Aug & 262.1 & 272.6 & 130.9 & 132.6 & 124.5 \\
& Sep & 261.4 & 270.8 & 130.5 & 131.8 & 122.8 \\
& Oct & 269.0 & 277.7 & 134.3 & 135.1 & 127.3 \\
& Nov & 256.6 & 274.5 & 128.1 & 133.6 & 117.5 \\
& Dec & 253.4 & 272.6 & 126.6 & 132.7 & 117.7 \\
\hline \multirow{3}{*}{2017} & Jan & 265.6 & 280.6 & 132.6 & 136.5 & 124.8 \\
& Feb & 260.7 & 278.6 & 130.2 & 135.5 & 122.2 \\
& Mar & 264.8 & 274.4 & 132.3 & 133.6 & 126.3 \\
& Apr & 268.2 & 278.6 & 134.0 & 135.5 & 127.7 \\
& May & 262.6 & 276.1 & 131.1 & 134.3 & 124.5 \\
& Jun & 258.6 & 269.5 & 129.1 & 131.2 & 123.8 \\
& Jul & 242.0 & 252.8 & 121.0 & 123.5 & 114.8 \\
& Aug & 214.8 & 219.8 & 108.0 & 108.7 & 107.3 \\
& Sep & 208.9 & 219.0 & 105.3 & 108.3 & 98.0 \\
& Oct & 203.6 & 209.0 & 102.9 & 103.9 & 98.0 \\
& Nov & 189.4 & 201.3 & 96.4 & 101.0 & 93.2 \\
& Dec & 190.2 & 203.2 & 96.7 & 101.4 & 92.9 \\
\hline
\end{tabular}

We obtained a graph that states the relationship between water availability with power generation PLTA PT Inalum duing 2015-2017 shown in Figure 2.

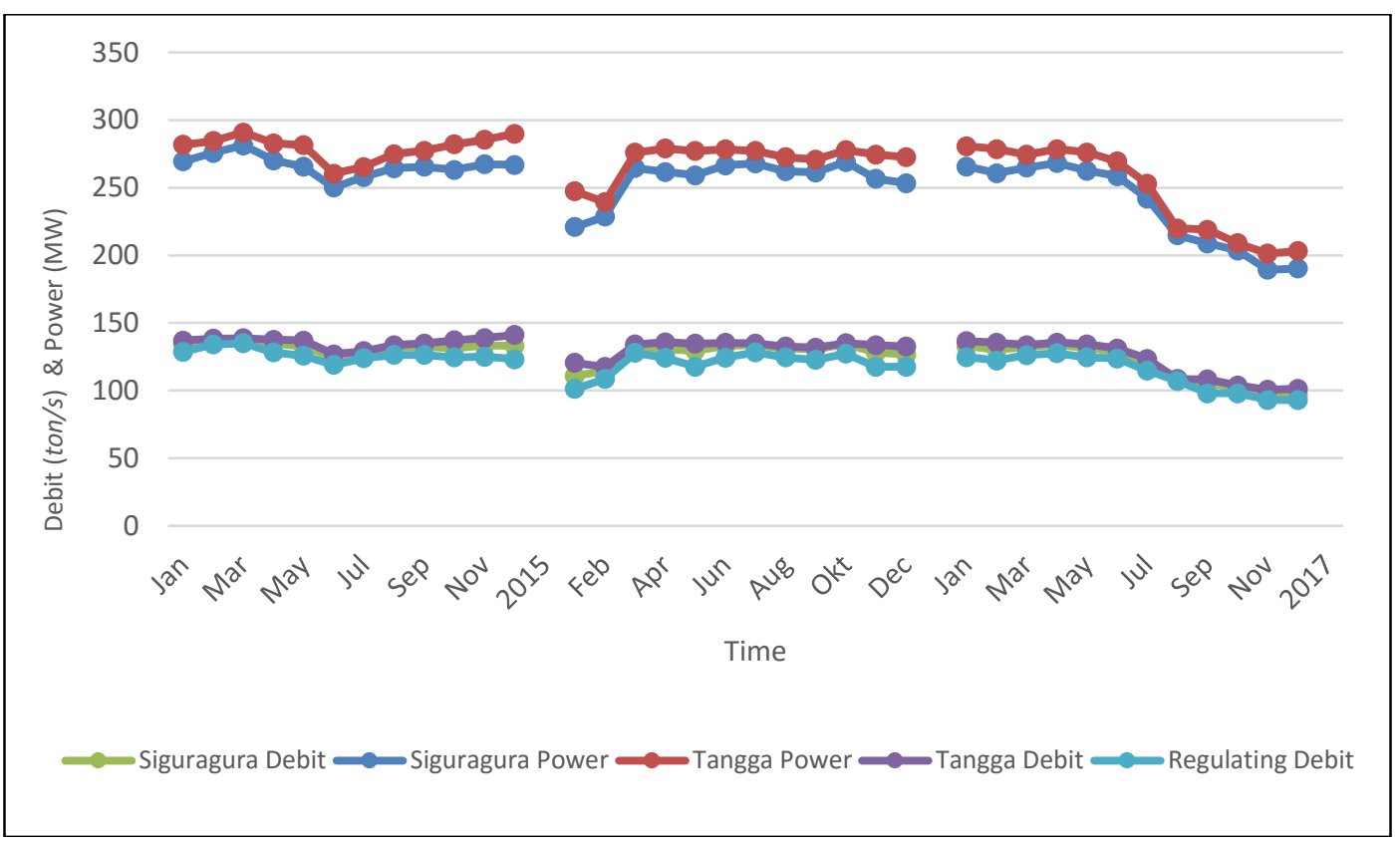

Figure 2. Graph of Water Balance calculation results 


\section{Conclusion}

Based on the results of the conducted research and analysis, the following conclusions are obtained:

1. The value of water debit to be issued is 134.05 ton / sec at peak load of $560.1875 \mathrm{MW}$ ie in February 2015.

2. Power generated was at amount 560.19 MW and at peak load around 560.1875 MW. The difference in power generated and power on the load side is due to the loss of power during the transmission process.

3. In the year 2015, there is an upward trend pattern where in December, the greatest water debit occurs at the end of year. In 2016, the trend pattern is relatively constant; there is no increase or decrease of drastic water debit. In the year 2017, the pattern of downward trend where there is large water discharge at the end of year.

\section{REFERENCES}

[1] E. Suryanto and J. T. Mesin, “Analisa Ketinggihan Dan Debit Air Pada Pembangkit,” pp. $1-6,2013$.

[2] P. Y. Tangkilisan, I. Hans, T. Mt, S. Silimang, and S. T. Mt, "Analisa Perhitungan Specific Water Consumption Pada Pembangkit Listrik Tenaga Air Di Sistem Minahasa," vol. 4, no. 5, pp. 27-36, 2015.

[3] S. M. and U. A. Tyas, E Cahyaning, "Studi Perencanaan Pembangkit Listrik Tenaga Air di Bendungan Pandanduri Swangi Lombok Timur Nusa Tenggara Barat," 2016.

[4] M. Pltmh et al., "Perancangan Turbin Francis Pembangkit Listrik Tenaga," pp. 1-12.

[5] LV Steeter, Mekanika Fluida, Jilid 1. Jakarta: Erlangga.

[6] O. Patty, Tenaga Air. Surabaya: Erlangga, 1995.

[7] M. Dandekar, Pembangkit Listrik Tenaga Air. Jakarta: Universitas Indonesia, 1991.

[8] Susatyo, Perancangan Turbin Pelton. Pusat Penelitian Informatika: LIPI.

[9] A. Arismunandar, Buku Pegangan Teknik Tenaga Listrik. Jakarta: PT. Pradnya Paramita, 2004.

[10] Yanziwar, "Perencanaan Turbin Cross Flow," 2017. .

[11] Inalum, "Bendungan Pengatur." [Online]. Available: http://www.inalum.id/article/bendungan-pengatur.html. [Accessed: 10-Aug-2017].

[12] Inalum, "Pembangkit Listrik Tenaga Air (PLTA)." [Online]. Available: http://www.inalum.id/article/ pembangkit-listrik-tenaga-air-plta.html. [Accessed: 10Aug-2017]. 